\title{
Geology of the Nelson Limestone, Postel Nunatak, Patuxent Range, Antarctica
}

\author{
KEVIN RAY EVANS ${ }^{1}$, LAWRENCE W. MCKENNA III ${ }^{2}$, BRUCE S. LIEBERMAN ${ }^{3}$, \\ WESLEY DONALD WEICHERT ${ }^{1}$ and KENNETH G. MACLEOD ${ }^{4}$ \\ ${ }^{1}$ Department of Geography, Geology \& Planning, Missouri State University, 901 S. National Avenue, Springfield, MO 65897, USA \\ ${ }^{2}$ Department of Physics \& Earth Science, Framingham State University, 100 State Street, PO Box 9101, Framingham, \\ MA 01701-9101, USA \\ ${ }^{3}$ Department of Ecology \& Evolutionary Biology \& Biodiversity Institute, 1345 Jayhawk Boulevard, The University of Kansas, \\ Lawrence, KS 66045, USA \\ ${ }^{4}$ Department of Geological Sciences, University of Missouri-Columbia, 101 Geological Sciences Building, Columbia, MO 65211, USA \\ kevinevans@missouristate.edu
}

\begin{abstract}
Postel Nunatak in the Patuxent Range has been previously mapped as Nelson Limestone but there was no biostratigraphic support for that interpretation until now. We confirm that limestone exposures at Postel Nunatak are at least partly correlated with the Nelson Limestone of the Neptune Range, $160 \mathrm{~km}$ north-east, and are not correlative with the lower Cambrian Schneider Hills Limestone of the Argentina Range. Upper beds have yielded the trilobites Suludella? davnii Palmer \& Gatehouse, 1972 and Solenopleura pruina Palmer \& Gatehouse, 1972, which provide a basis for assignment to Cambrian Series 3 (late middle Cambrian), within the Drumian or lower Guzhangian stages. Limestone beds were deposited in a shallow marine setting, ranging from supratidal to lagoonal facies with rare subtidal intervals. These settings contrast with deeper water facies of the Neptune Range. Despite limitations in sampling density, isotopic analysis indicates that a greater than $+2.5 \%$ shift in $\delta^{13} \mathrm{C}$ is consistent with $\delta^{13} \mathrm{C}$ trends documented for the Drumian Stage. Because the upper and lower contacts at Postel Nunatak are covered by snow and ice, the relationship with rocks mapped as the Patuxent Formation in the Patuxent Range remains uncertain, but part of it may belong to the Precambrian Hannah Ridge Formation.
\end{abstract}

Received 21 February 2017, accepted 19 July 2017, first published online 2 November 2017

Key words: Hannah Ridge Formation, middle Cambrian, Nelson Limestone, Patuxent Formation, Pensacola Mountains, Series 3

\section{Introduction}

Exposed rock represents only $0.18 \%$ of the surface area on the continent of Antarctica (Burton-Johnson et al. 2016). Outcrops are concentrated in mountain ranges along the Transantarctic Mountains and in peripheral regions such as the Antarctic Peninsula, Ellsworth Mountains and in a few areas around the eastern perimeter of the continent. Because of the lack of exposure, exploration of remote mountain ranges and nunataks (isolated peaks surrounded by snow and ice) provide important sources of data for our understanding of continental-scale tectonic events and Antarctic geologic history. This paper presents new faunal evidence that confirms the age and stratigraphic position of limestone exposures at Postel Nunatak in the Patuxent Range, which had been mapped as middle Cambrian Nelson Limestone (Schmidt \& Ford 1969); it also provides an interpretation of the depositional setting of the limestone, presents a reconnaissance-level survey of variations in stable isotopes of carbon and oxygen in carbonate rock samples, and discusses the broader implications of these data for regional correlation of Nelson Limestone and adjacent strata of uncertain stratigraphic affinities in the Patuxent Range.

Research efforts on the Cambrian rocks of Antarctica over the last two decades have refined our understanding of the timing and tectonic setting of the Cambrian to Ordovician Ross Orogeny (Rowell et al. 1992, 2001, Stump 1995, Storey et al. 1996, Curtis 2002, Curtis \& Storey 2003, Curtis et al. 2004, Federico et al. 2009). Evidence of deformation during the Ross Orogeny is expressed along the entire margin of East Antarctica from northern Victoria Land to the Pensacola Mountains, in some of the peripheral terranes and across the Australian margin of western Gondwana. Deformation probably resulted from accretion and partial obduction of an arc (back-arc) trench system, a collision which Federico et al. (2009) argued occurred during the opening and closing of a back-arc basin, similar to the Cambrian 

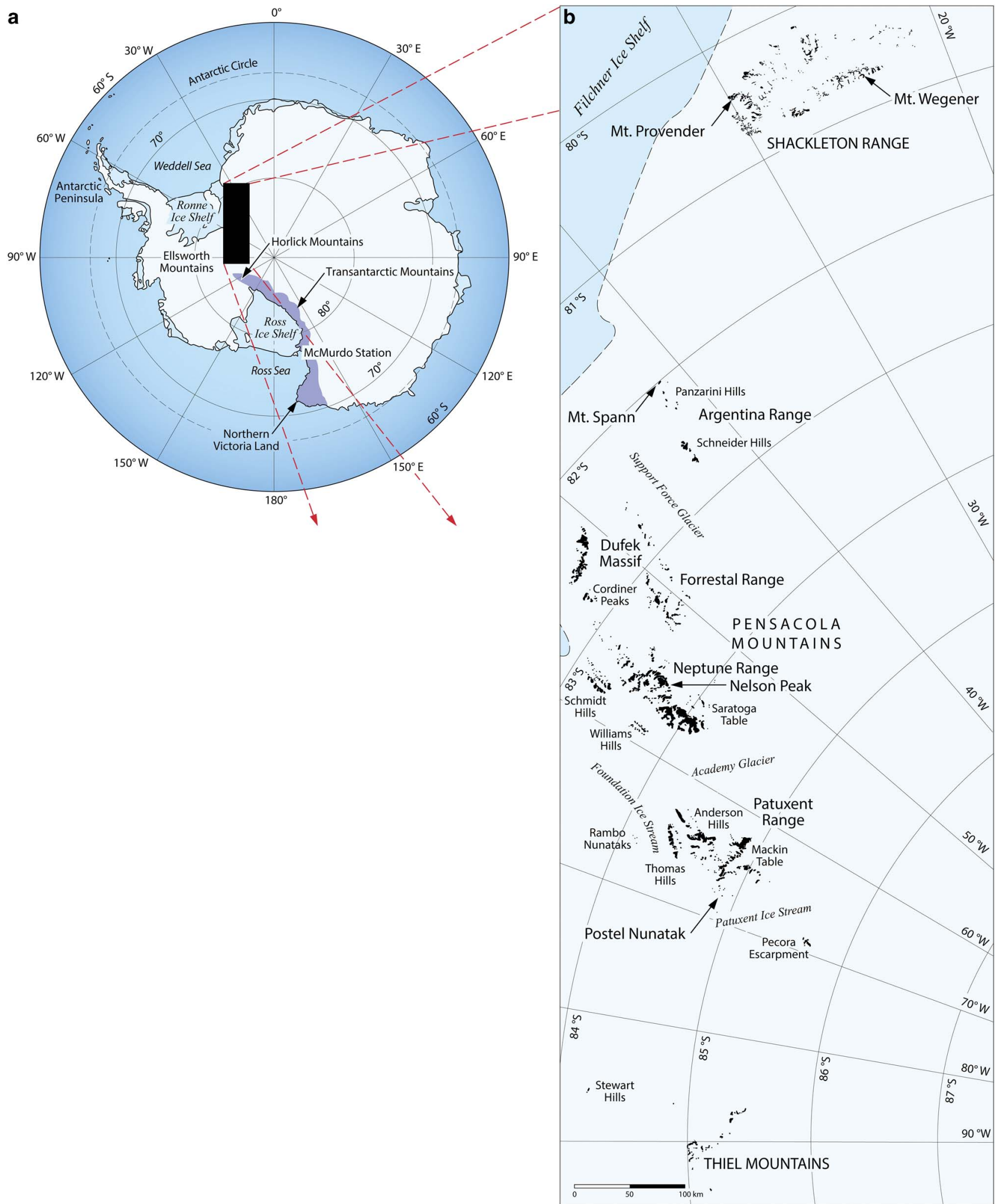

Fig. 1a. Map of Antarctica. b. Detailed map showing the Pensacola Mountains and adjacent areas mentioned in the text (see Fig. 9).

record of the South Island of New Zealand. If this comparison is correct, accretion during this orogeny need not have involved collision with a major terrane or continental landmass. In the Pensacola Mountains, Curtis et al. (2004) have proposed a model for episodes of both contractional and extensional deformation 


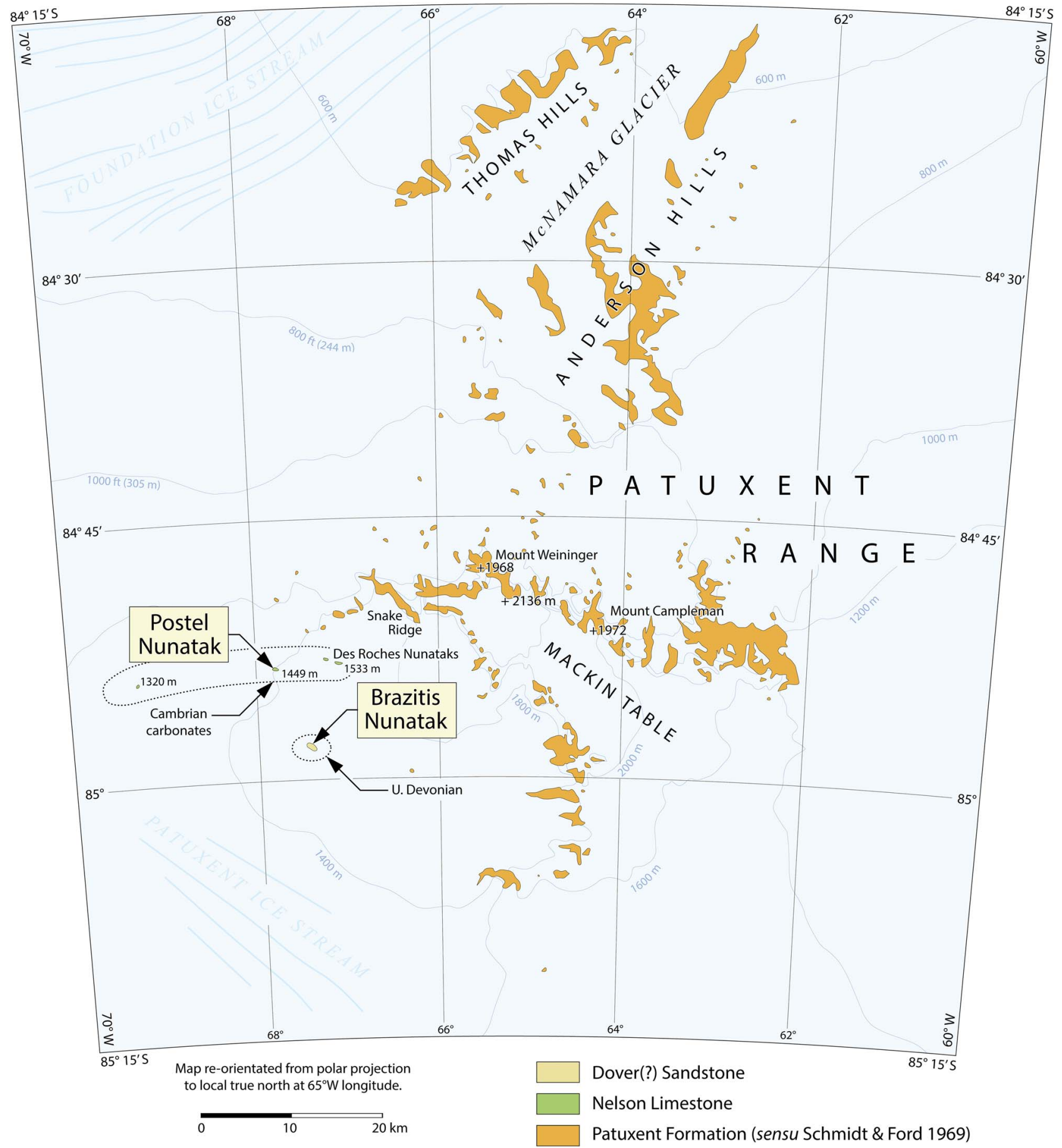

Fig. 2. Map of Patuxent Range including parts of US Geological Survey Antarctica 1:250 000 topographical reconnaissance maps for the Thomas Hills and Pecora Escarpment quadrangles. Distribution of the limestone outcrops mapped as Nelson Limestone and Devonian Sandstone in Brazitis Nunatak is shown in Schmidt \& Ford (1969). All other outcrops were mapped as Patuxent Formation.

related to low-angle and normal subduction of oceanic platforms. Lower and middle Cambrian carbonate lithosomes bracketed (i.e. were deposited before and after) the onset of the Ross Orogeny. The distribution of both lower and middle Cambrian carbonates, their ages, thicknesses and depositional settings therefore assume importance for our understanding of the timing, extent and significance of intra-orogenic processes such as subsidence and relative quiescence along this active tectonic margin. 


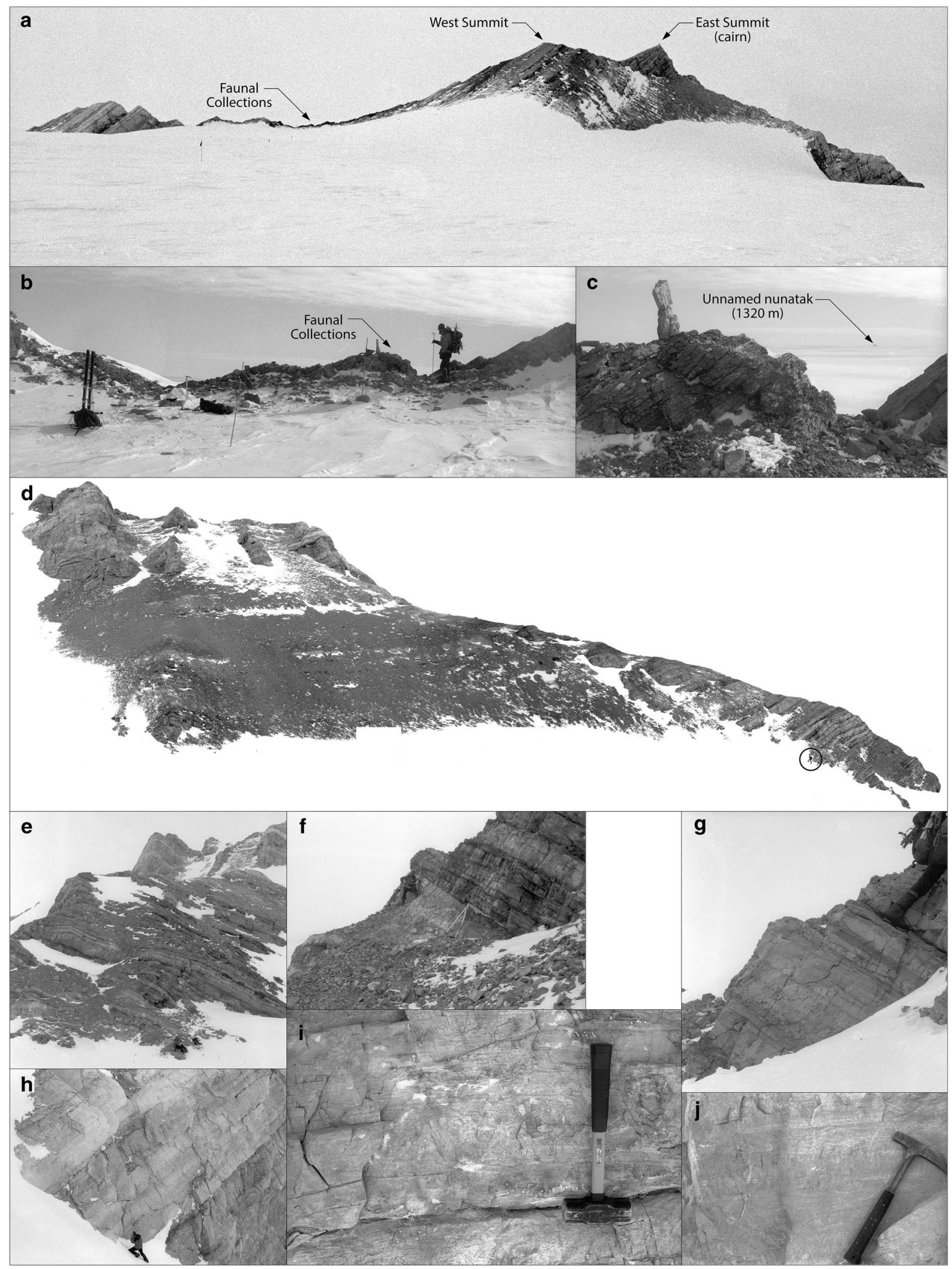

Fig. 3. Outcrop images. a. Postel Nunatak from east; beds dip southward. b. Sample locality E93-06. c. Close-up of E93-06. Trilobites were collected from dark grey beds. d. Oblique composite photo of lower Postel Nunatak (person circled). e. Base of stratigraphic section. f. Lower beds $c$. $6 \mathrm{~m}$. Resistant beds of intraclastic conglomerate and peloid grainstone above top of Jacob's staff. g. Peloid grainstone and microbialites above burrowed lime mudstone. Boot at $39 \mathrm{~m}$. h. Thick beds of burrowed and fenestral mudstone. Person at $190.5 \mathrm{~m}$. i. Laminated mudstone at $244 \mathrm{~m}$. j. Laminated and fenestral mudstone from upper section. 


\section{Location}

The Pensacola Mountains are located at the Weddell Sea terminus of the Transantarctic Mountains (Fig. 1). Exposed rocks in the mountain ranges that comprise the Pensacola Mountains are separated more widely than more-or-less contiguous exposures that stretch from northern Victoria Land to the Horlick Mountains. Large areas of relatively well-exposed rock in the Pensacola Mountains include, from south-west to northeast, the Pecora Escarpment, Patuxent Range, Rambo Nunataks, Neptune Range (including the Schmidt Hills and Williams Hills), Forrestal Range, Cordiner Peaks, Dufek Massif and Argentina Range (including the Panzarini Hills and Schneider Hills). The Shackleton Range is not part of the Pensacola Mountains and is located c. $240 \mathrm{~km}$ north-east of the Argentina Range. The Thiel Mountains are also separate from the Pensacola Mountains and are located c. $180 \mathrm{~km} \mathrm{W-SW}$ of the Pensacola Mountains (Fig. 1).

The Patuxent Range is shown on US Geological Survey 1:250,000 Antarctic reconnaissance series maps for the Thomas Hills and northern part of the Pecora Escarpment quadrangles. It consists of a series of relatively lowelevation peaks and ridges between the Foundation and Patuxent ice streams (Fig. 2). The main parts include the Thomas Hills, Anderson Hills, Mackin Table, and clusters of nearby nunataks and isolated ridges. One of these isolated outcrops is Postel Nunatak, which is located near the western edge of the Patuxent Range $c .6 \mathrm{~km}$ west of the Des Roches Nunataks, the nearest bedrock exposures.

\section{Previous studies}

Field parties from the US Geological Survey first explored the geology of the Patuxent Range in 1962-63 (see Schmidt \& Ford 1969). Geologic mapping of the remainder of the Pensacola Mountains and Thiel Mountains followed during the 1963-64 and 1965-66 field seasons. Previous studies of the Nelson Limestone are limited to the initial lithologic descriptions of the unit from the Neptune Range (Schmidt et al. 1964, 1978), descriptions of fauna collected there and from correlative exotic moraine material (Palmer \& Gatehouse 1972, Palmer \& Rowell 1995, Lieberman 2004, BassettButt 2016), and subsequent sequence-stratigraphic studies (Evans et al. 1995). On the geologic map of the Pensacola and Thiel mountains, which included the Patuxent Range, the Nelson Limestone was mapped at the Des Roches Nunataks, Postel Nunatak and an unnamed nunatak with an elevation of $1320 \mathrm{~m}$ (see Fig. 3c; Schmidt $\&$ Ford 1969). Although these limestone outcrops were mapped as Nelson Limestone, no detailed descriptions of the geology nor corroborative evidence correlating these limestone exposures using fauna has been published until now.
Most subsequent studies of Palaeozoic rocks in the Pensacola Mountains have focused field efforts in places other than the Patuxent Range, but Curtis (2002) visited Snake Ridge and Mount Campleman along the northern edge of Mackin Table, where he collected additional structural data from the Patuxent Range. These data were used to develop a high-resolution structural interpretation that suggested multiple phases of deformation and were integrated with an isotope geochronology and kinematic model for shallowly focused deformation in the Pensacola Mountains. In short, the polyphase deformation was interpreted as spanning the earliest to latest phases of the Ross Orogeny with the latest phase of deformation most conspicuous (Curtis \& Storey 2003, Curtis et al. 2004, see also Rowell et al. 1992, 2001, Storey et al. 1996). Understanding the tectonic history relies on isotope geochronology as well as faunal collections and regional patterns of sedimentation.

Cambrian biostratigraphy in Antarctica is based largely on trilobites and several papers have considered this subject in detail. Complete consideration of the literature on this topic would require extensive discussion and goes beyond the scope of the present work. Here, only an entry into the literature is provided. In particular, Palmer \& Gatehouse (1972) used material, primarily collected from boulders in moraines, to establish a preliminary Cambrian biostratigraphy for parts of the continent, with special focus on the Transantarctic Mountains. Soloviev \& Grikurov (1978, 1979) presented additional discoveries of trilobites from this region. Subsequently, Palmer \& Rowell (1995) extended this work with a detailed analysis of early Cambrian (Series 2) trilobite faunas from the Schneider Hills. Lieberman (2004) provided additional details on the systematics and biostratigraphy of the Cambrian trilobite faunas from the Transantarctic Mountains, especially fossils from the Nelson Limestone, where it crops out in the Neptune Range, and provided biostratigraphic revisions for strata consigned to Cambrian Series 3 .

Trilobite faunas have also been recovered from other parts of Antarctica as well. For example, Cooper et al. (1996), Wolfart (1994), Jago \& Cooper (2007), Jago et al. (2011) and Bentley et al. (2016) provided information on the systematics and biostratigraphy of Cambrian trilobites from northern Victoria Land. Soloviev et al. (1984) and Jago \& Webers (1992) focused on the systematics and taxonomy of Cambrian trilobites from West Antarctica. Finally, Encarnación et al. (1999) also included information on Cambrian trilobites, and their bearing on the regional biostratigraphy, from the Dronning Maud Mountains.

\section{Methods and materials}

Studies of the Pensacola Mountains during the 1993-94 field season focused on collection of igneous rock samples 
Table I. E93-06 (Postel Nunatak) sample lithology descriptions (see Fig. 7) and isotopic composition values (see Fig. 8) of replicates from bottom, middle and top of each sample, respectively.

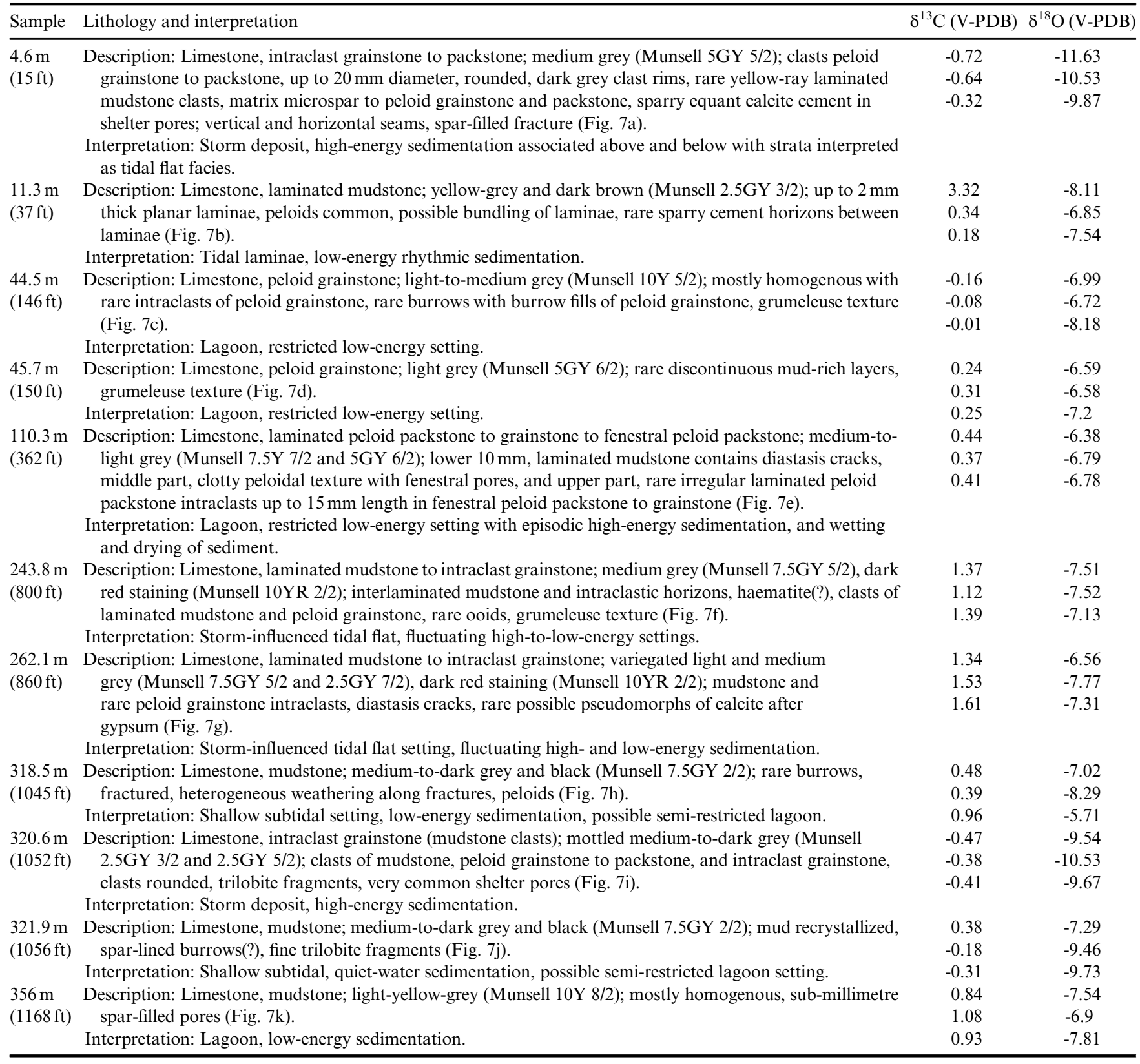

V-PDB = Vienna-PeeDee Belemnite.

from the Schmidt Hills, Williams Hills and Washington Escarpment in the Neptune Range for isotope geochronology studies (Van Schmus et al. 1997), examination of field relationships associated with the Nelson Limestone, Gambacorta Formation and Wiens Formation (Evans et al. 1995, Rowell et al. 2001), and exploration of the stratigraphic succession in the Patuxent Range. Air transportation support in the Pensacola Mountains was provided by a de Havilland Twin Otter, which made it possible to visit and collect from remote areas that otherwise would have been inaccessible.
On 29 November 1993, McKenna and Evans landed in the Patuxent Range, c. $2.5 \mathrm{~km}$ east of Postel Nunatak. Fieldwork at this locality was completed on 30 November 1993. A stratigraphic section was measured and described, and trilobite parts and fragments were collected between $318-322 \mathrm{~m}$. In addition to crack-out collections, $c .15 \mathrm{~kg}$ of bulk rock samples were taken from the outcrop. The entire excursion transpired in $c$. 36 hours. Deteriorating weather conditions required air extraction from the landing site on 1 December 1993 and return to the put-in site and base camp in the Roderick Valley of the Neptune Range. 

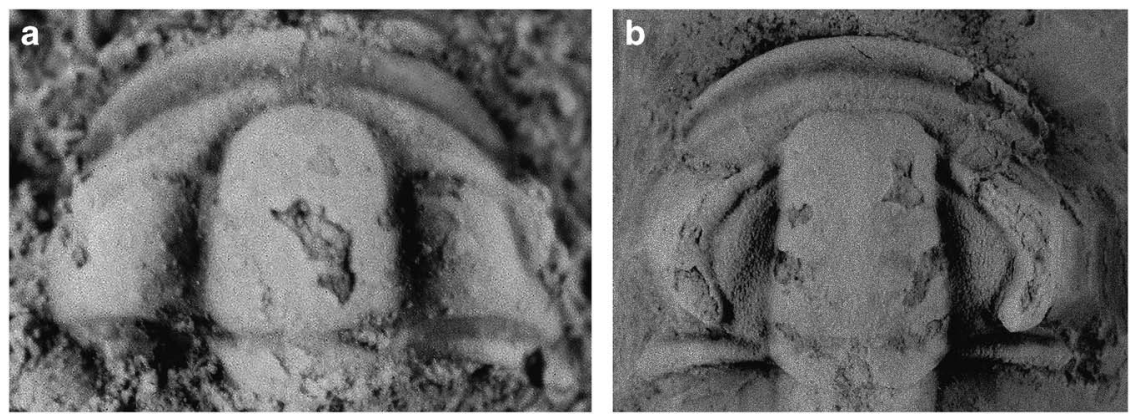

Fig. 4. Images of trilobites collected in sample E93-06 from $c .318-322 \mathrm{~m}$ in the measured stratigraphic section. a. Solenopleura pruina shown $\times 22$. b. Suludella? davnii shown $\times 5$.

Bulk faunal sample E93-06 was split and partly prepared by Evans and Rowell in 1994 and is currently housed in the University of Kansas Biodiversity Institute, Division of Invertebrate Paleontology (KUMIP). Specimens have been evaluated further by Lieberman herein. Additionally, 11 hand samples were collected from the measured stratigraphic section and prepared as polished slabs representative of different depositional facies (Table I).

The obverse sides of the polished slabs were prepared for carbonate carbon and oxygen stable isotopic analysis by washing in an ultrasonic bath and rinsing in deionized water prior to drilling to generate powders for analysis. Three samples were drilled from each slab for a total of 33 samples. Homogenous lime mudstone layers were targeted and microdrilled from surfaces without obvious secondary diagenetic features. Carbonate carbon $\left(\delta^{13} \mathrm{C}\right)$ preserved in mudstone has been shown to be resistant to alteration over a range of diagenetic settings encountered in carbonate successions, whereas $\delta^{18} \mathrm{O}$ is easily reset during diagenesis (O’Neil 1987).
Measurements of carbon $\left(\delta^{13} \mathrm{C}\right)$ and oxygen $\left(\delta^{18} \mathrm{O}\right)$ isotopic values were made at the University of Missouri biogeochemistry stable isotope laboratory. Approximately $50 \mu \mathrm{g}$ of powdered carbonate was reacted with $103 \%$ phosphoric acid for four minutes at $70^{\circ} \mathrm{C}$ using a Kiel III automated carbonate device from Thermo Fisher Scientific. Evolved $\mathrm{CO}_{2}$ gas was cryogenically cleaned and analysed on a Thermo Finnigan DeltaPlus mass spectrometer operated in dual inlet mode. Results were normalized to the National Bureau of Standards (NBS)-19 standard with nominal values of $-2.20 \%$ and $+1.95 \%$ o for $\delta^{18} \mathrm{O}$ and $\delta^{13} \mathrm{C}$, respectively. Results for uncorrected measurements of NBS-19 run during the course of the study indicate an external analytical precision of $0.02 \% \circ( \pm 1 \sigma)$ for $\delta^{13} \mathrm{C}$ and $0.06 \%$ o $( \pm 1 \sigma)$ for $\delta^{18} \mathrm{O}$ values. All results are reported in delta $(\delta)$ notation relative to the Vienna-PeeDee Belemnite (V-PDB) scale.

Trilobites were recovered from the upper burrowed lime mudstone beds from $318-322 \mathrm{~m}$, in what is referred to as sample E93-06 in the KUMIP collections (Fig. 4). One set of specimens possess the diagnostic and

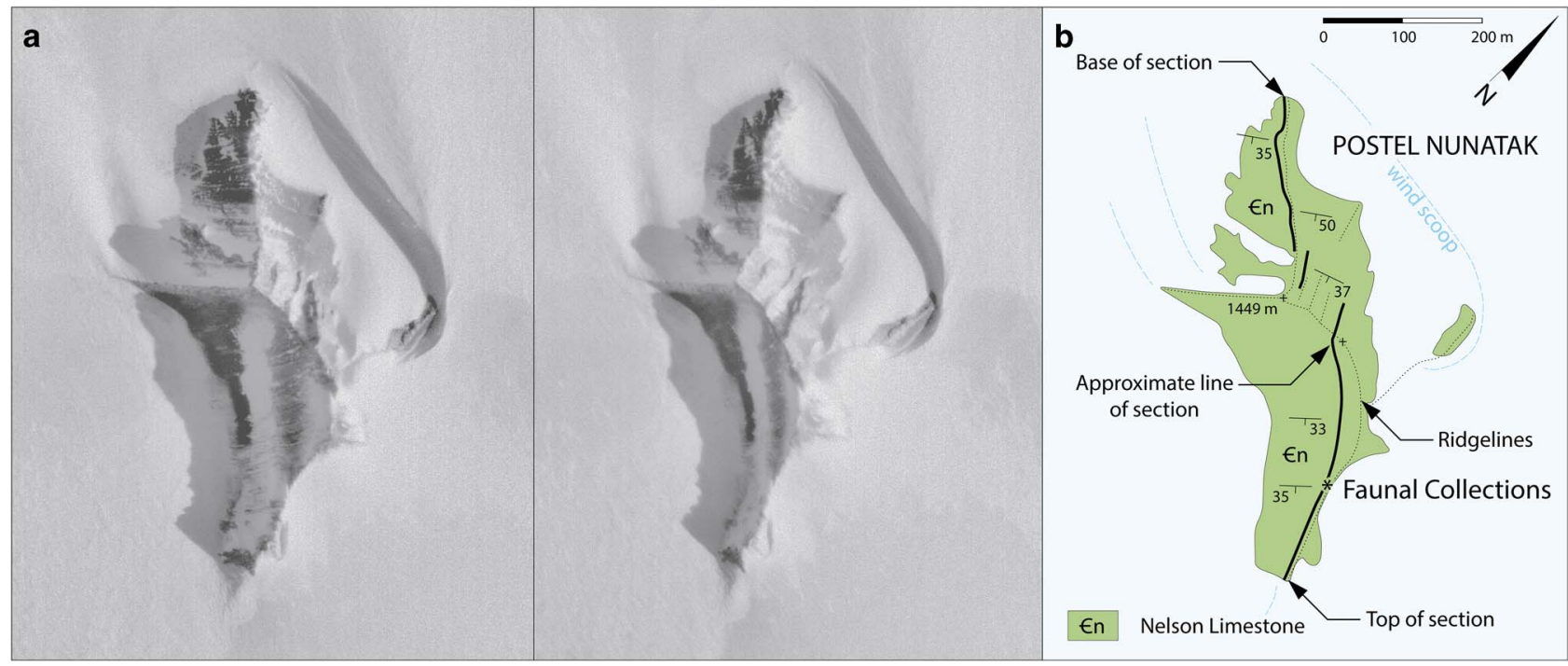

Fig. 5a. Stereoscopic aerial photographs of Postel Nunatak, numbers TMA 1503-336 and -337, taken 17 December 1964.

b. Geologic map of Postel Nunatak. Approximate line of stratigraphic section indicated by bold black lines. Location of sample E93-06 shown with an asterisk. East summit (elevation $1449 \mathrm{~m}$ ) and west summit indicated by plus signs. 
characteristic features of Solenopleura pruina presented in Palmer \& Gatehouse (1972) and Lieberman (2004). Solenopleura pruina has previously been documented from morainal boulders recovered on Mount Spann in the Argentina Range (Palmer \& Gatehouse 1972, Soloviev \& Grikurov 1979), and from several localities and stratigraphic levels of the Nelson Limestone in the Neptune Range (Lieberman 2004); indeed, it is among the most common trilobites in the Nelson Limestone in the Neptune Range. Palmer \& Gatehouse (1972) indicated S. pruina was moderately common in the moraine boulder from Mount Spann as well. The species closely resembles other species assigned to Solenopleuridae in general, and Solenopleura Angelin, 1854 in particular, that have been described from northern Victoria Land by Wolfart (1994) and Cooper et al. (1996), and from West Antarctica by

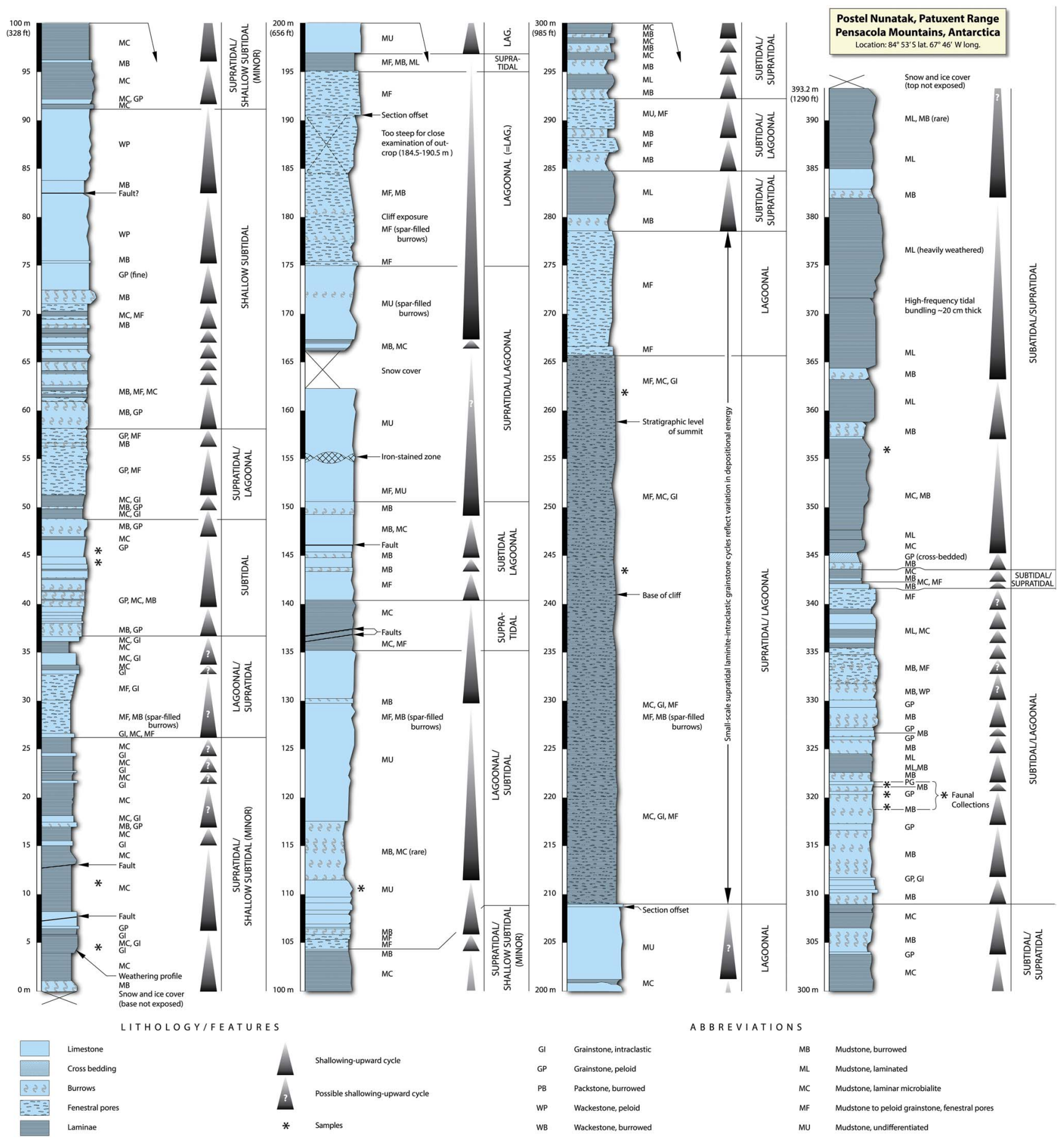

Fig. 6. Measured and described stratigraphic section at Postel Nunatak. 


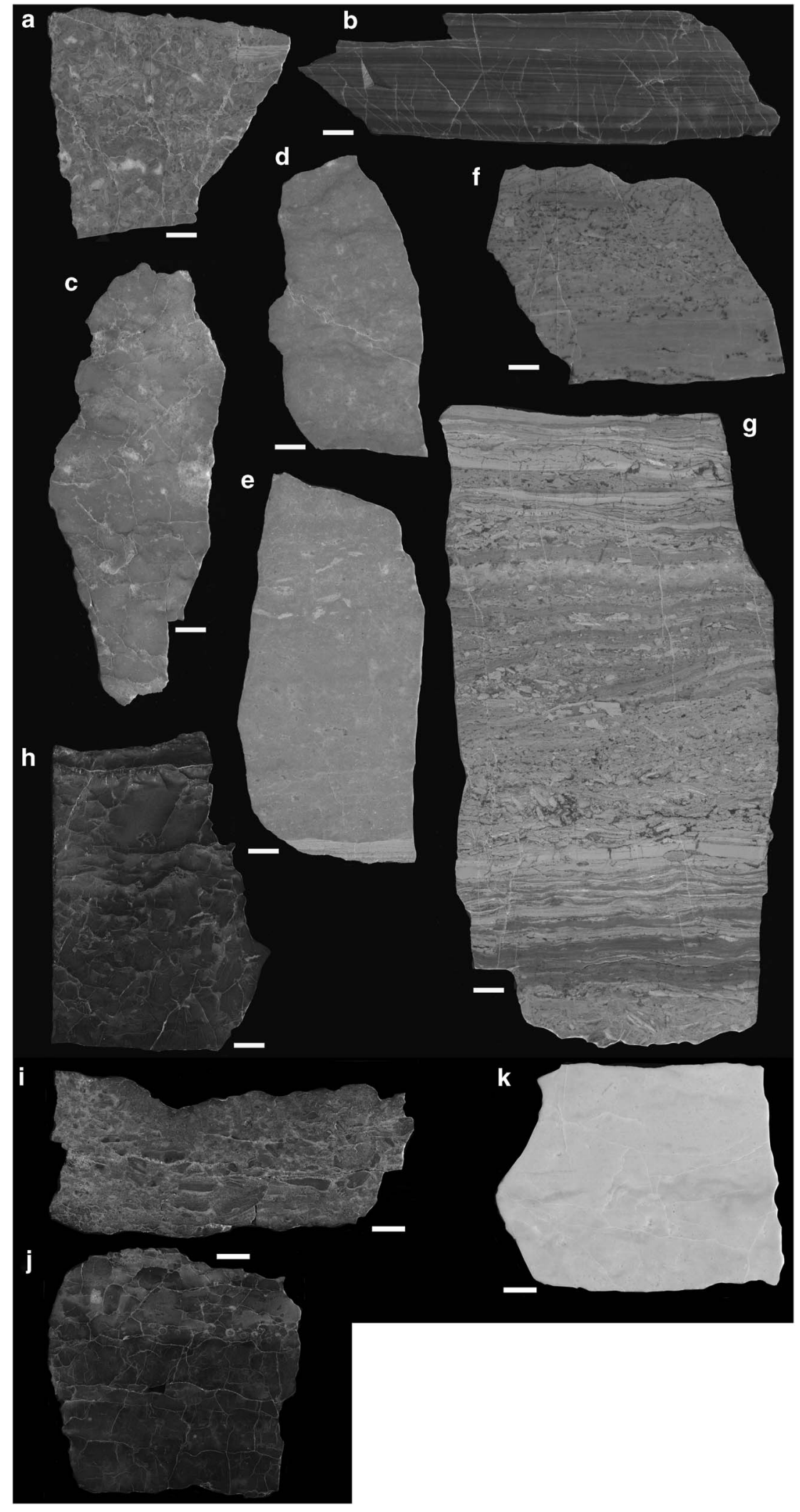

Fig. 7. Polished limestone slabs representative of lithofacies at Postel Nunatak (see Table I for detailed descriptions and values of stable isotopes). a. Intraclast grainstone to packstone $(4.6 \mathrm{~m})$, b. laminated lime mudstone $(11.3 \mathrm{~m})$, c. peloid grainstone $(44.5 \mathrm{~m})$, d. peloid grainstone $(45.7 \mathrm{~m})$, e. laminated peloid packstone to grainstone to fenestral peloid packstone $(110.3 \mathrm{~m})$, f. laminated lime mudstone to intraclast grainstone $(243.8 \mathrm{~m})$, g. laminated lime mudstone to intraclast grainstone $(262.1 \mathrm{~m})$, h. lime mudstone $(318.5 \mathrm{~m})$, i. intraclast grainstone with lime mudstone clasts $(320.6 \mathrm{~m})$, j. lime mudstone $(321.9 \mathrm{~m})$ and k. lime mudstone $(356 \mathrm{~m})$. 
Jago \& Webers (1992) (see Lieberman 2004 for further discussion). Solenopleura pruina is rare at Postel Nunatak and represented by KUMIP 416072 and questionably KUMIP 416073.

Another set of trilobite specimens possess the diagnostic and characteristic features of $S$.? davnii presented in Palmer \& Gatehouse (1972). Suludella? has previously been reported from a boulder in a moraine on Mount Spann in the Argentina Range, where it is represented by S.? davnii and S.? spinosa, and from two localities in the Neptune Range, where it is represented only by S.? spinosa (Lieberman 2004). It was also reported from northern Victoria Land by Wolfart (1994), though the material is so incomplete and poorly preserved that it was difficult to verify this taxonomic assignment (Lieberman 2004). Palmer \& Gatehouse (1972) also discussed why the Antarctic material could only be questionably assigned to Suludella (a genus defined initially on material from Siberia); since there have not been any phylogenetic or substantive taxonomic revisions to the genus subsequent to that publication, we follow the uncertain generic assignment. Suludella? davnii is more abundant than S. pruina and is represented by several cranidia and librigena (KUMIP 407995, 497996 and 416069-416071) as well as a partial pygidium (KUMIP 407997). No other trilobite species were identified in the material recovered from the Postel Nunatak.

\section{Results}

\section{Lithostratigraphy}

Beds on Postel Nunatak dip south-east at angles ranging from $c .30^{\circ}$ to $50^{\circ}$ (Figs $3 \& 5$ ). The base for the measured stratigraphic section was established at the north-west end of the nunatak. The line of section followed a series of ridgelines, ran along the sides of prominent cliffs and was offset between scree and snow-covered couloirs (Figs 3, $5 \&$ 6). The uppermost part of the section followed a dip-slope and ridgeline to the south-east. A few faults with minor offset were crossed in the line of section (Fig. 6); however, although the potential existed for more significant offset along bedding planes, bedding was generally continuous on the scale of a few metres to tens of metres along strike. The distribution of Nelson Limestone outcrops in the Patuxent Range would be consistent with one or more long fold axes between older strata to the north and east and younger strata to the south (see Fig. 2).

The $393 \mathrm{~m}$ thick succession consists mostly of lime mudstone and peloid grainstone (Table I, Fig. 7). There is little variation in lithofacies and about ten common carbonate rock types are present. The dominant lithofacies include thick intervals of regular and irregular laminae to thin beds of lime mudstone (Fig. 7b $\&$ f), intervals of intraclast conglomerate composed of ripup clasts (up to $3 \mathrm{~cm}$ in length) of laminae from laminated lime mudstone (Fig. $7 \mathrm{~g}$ ), thin intervals of burrowed lime mudstone to wackestone to grainstone (Fig. 7c-e, h, j \& k; some of which have yielded trilobites carapaces, Fig. 7h), thin to medium beds of peloid grainstone and wackestone; and thick and massive beds of peloid grainstone, with and without sparry calcite burrow fills and fenestral pores (Fig. 7a \& i). At both the top and the bottom portions of the measured section, lithofacies were interbedded on the scale of $0.5-5 \mathrm{~m}$. However, in the middle part of the exposure, a thick interval of monotonous fenestral mudstone seems to record a markedly long period of depositional stasis. One rare a

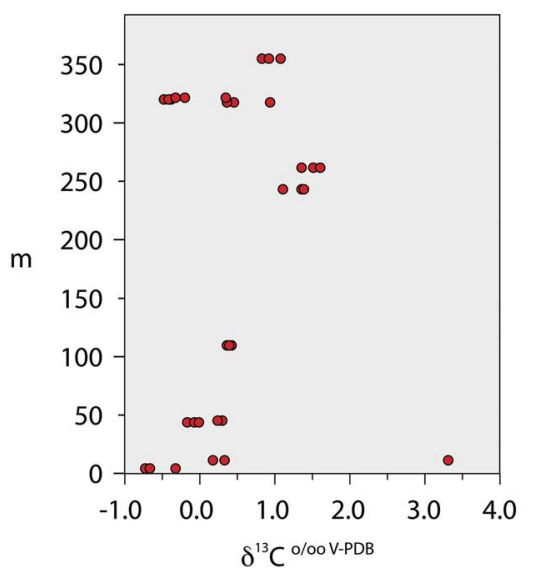

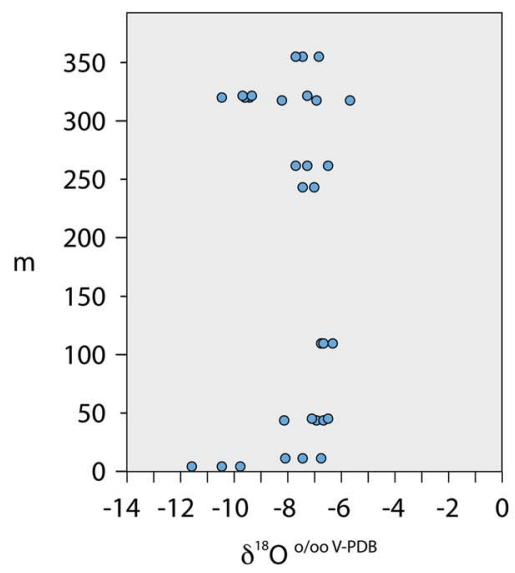

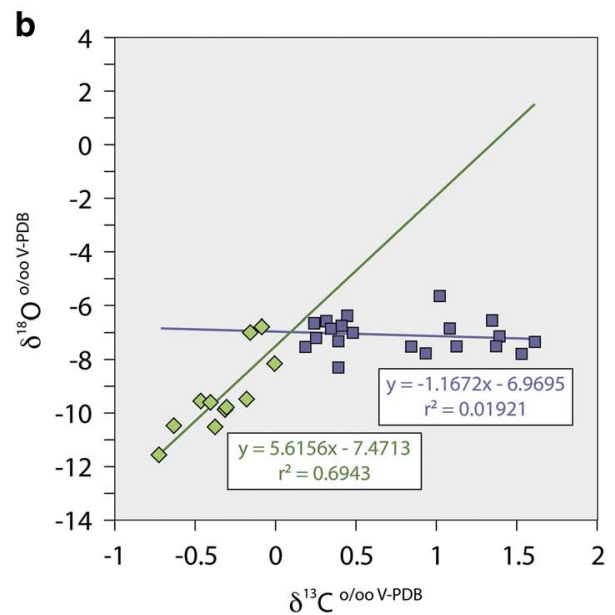

Fig. 8a. $\delta^{13} \mathrm{C}$ and $\delta^{18} \mathrm{O}$ values (x-axes) plotted against stratigraphic position in the measured stratigraphic section (y-axes). b. Cross-plot of $\delta^{13} \mathrm{C}$ and $\delta^{18} \mathrm{O}$, excluding subsamples with anomalously high values. Note the marked deviation, which is interpreted as a product of alteration in $\delta^{18} \mathrm{O}$. Lines of correlation and Pearson's products are shown for the two subpopulations. $\mathrm{V}-\mathrm{PDB}=$ Vienna-PeeDee Belemnite. 
cross-bedded peloid grainstone is present in the upper part of the section at $245 \mathrm{~m}$. In the upper part of the section, c. $370 \mathrm{~m}$, beds of laminated lime mudstone show more regular layering and seem to be bundled in upward thinning and upward thickening packages that range to $>20 \mathrm{~cm}$ thick.

\section{Stable isotopes of carbon and oxygen}

Hand samples were used to survey a gross-scale trend in the stable isotopic signature of the carbonate succession (Table I, Figs $7 \& 8$ ). For the 33 samples analysed, values for $\delta^{18} \mathrm{O}$ ranged from -11.63 to $-6.38 \%$, and values for $\delta^{13} \mathrm{C}$ ranged from 3.63 to $-0.72 \%$ o (Table I). Low values for $\delta^{18} \mathrm{O}$ are expected for bulk carbonate analyses of early Palaeozoic limestone and suggest a diagenetic overprint at elevated temperatures during burial and lithification. The anomalously high value for $\delta^{13} \mathrm{C}$ was obtained from powder from an unusual dark lamina in the lower part of a laminated lime mudstone (Fig. 7b). In other samples, variation among the three positions drilled on each sample tend to be less than or equal to differences in values averaged for each sample. The lowest $\delta^{13} \mathrm{C}$ values were associated with the intraclast grainstone to packstone sample collected near the base of the section (Fig. 7a). Two additional samples were re-analysed and similar results were obtained from each. The $\delta^{13} \mathrm{C}$ and $\delta^{18} \mathrm{O}$ measurements are positively correlated (overall $r^{2}=0.43$ with the anomalous $\delta^{13} \mathrm{C}$ omitted) but the correlation seems to result from the values for samples with the lowest $\delta^{13} \mathrm{C}$ values $\left(<0 \%\right.$ ). In samples with $\delta^{13} \mathrm{C}$ values $<0 \%$ o there is a strong positive correlation between $\delta^{13} \mathrm{C} \delta^{18} \mathrm{O}$ values $\left(r^{2}=0.69\right)$ whereas there is no correlation between the two measures $\left(r^{2}=0.02\right)$ for samples with $\delta^{13} \mathrm{C}$ values $>0 \%$ (Fig. 8 b). Positive correlation suggests alteration as do the low $\delta^{18} \mathrm{O}$ values. However, the bend in the isotopic cross-plot at $\sim \delta^{13} \mathrm{C}=0 \%$ o suggests that diagenetic carbon from a different source (perhaps remineralized organic matter) is a major confounding variable only in the most altered samples and less altered samples may have $\delta^{13} \mathrm{C}$ values close to original values consistent with the generality that $\delta^{13} \mathrm{C}$ is a more robust than $\delta^{18} \mathrm{O}$ values in carbonate-rich systems.

\section{Discussion}

The analysis of sediments and trilobites recovered from an extensive $393 \mathrm{~m}$ thick succession in the Postel Nunatak provides new insights into the age relationships of this Cambrian deposit and suggests a close stratigraphic association with the Neptune Limestone in the Neptune Range. In particular, the fauna suggests the unit lies within Cambrian Series 3, and is either Drumian or Drumian plus Guzhangian in age. Additional analysis of the relationships of this unit to equivalent as well as overlying and underlying strata may ultimately provide further insight into the regional geology of Antarctica and the timing of the Ross Orogeny. Thus, some of these other deposits warrant mentioning. For instance, Series 2 and 3 (early and middle) Cambrian limestones or correlative siliciclastic strata are exposed across part of the Transantarctic Mountains to the Shackleton Range. Both Cambrian Series 2 and 3 faunas have been recovered from blocks in moraines near Mount Spann in the Panzarini Hills of the northern Argentina Range (Palmer \& Gatehouse 1972). Series 2 Cambrian limestone reefs are present in the Schneider Hills (Rowell et al. 1992). Cambrian Series 2 (and older) limestones are missing in the Neptune Range and presumably were removed by uplift and erosion during an early phase of the Ross Orogeny. Cambrian Series 2 (and older) strata equivalent to the Schneider Hills Limestone may be missing in the Patuxent Range, or they may be covered by snow and ice.

The interpretation of carbonate facies relies on modern analogues. Irregular laminae and thin beds of lime mudstone compare favourably with planar microbialites. Planar microbialites (including stromatolites) are common in Florida Bay tidal island interiors, where episodic wetting and drying of sediment has led to development of thick successions of irregularly laminated carbonate muds with desiccation cracks, interstratified with binding organic material (Enos \& Perkins 1979). Lime mudstone intervals that contain regular laminae and thin beds often occur in bundles with marked thickening and thinning that would suggest episodic slack-water deposition. These features are comparable to laminae that have been influenced by tides and lunar cycles and are interpreted as tidal laminites (Ginsburg 1975). Both regular and irregular varieties of laminated mudstone accumulated in shallow water ranging from upper intertidal to supratidal settings (Wilson 1975). Intraclast conglomerates are commonly associated with both regular and irregular laminated mudstone facies and tend to have preserved shelter pores. Such lithologies are interpreted as storm deposits (Ager 1974).

The lime mudstone to peloid grainstone facies is interpreted as having accumulated in a shallow water lagoonal setting. Fenestral pores indicate wetting and drying of the sediment. Rare to common burrows indicate marine deposition in a well-oxygenated, normal to somewhat restricted salinity setting. Burrows in these massively bedded intervals were commonly filled with sparry calcite, which indicates relatively rapid cementation early in the diagenetic history of this succession. Equant calcite spar is consistent with meteoric diagenesis where sediments may have been exposed to freshwater dissolution and subsequent precipitation of sparry carbonate cement. Faint horizontal laminae within these successions would 


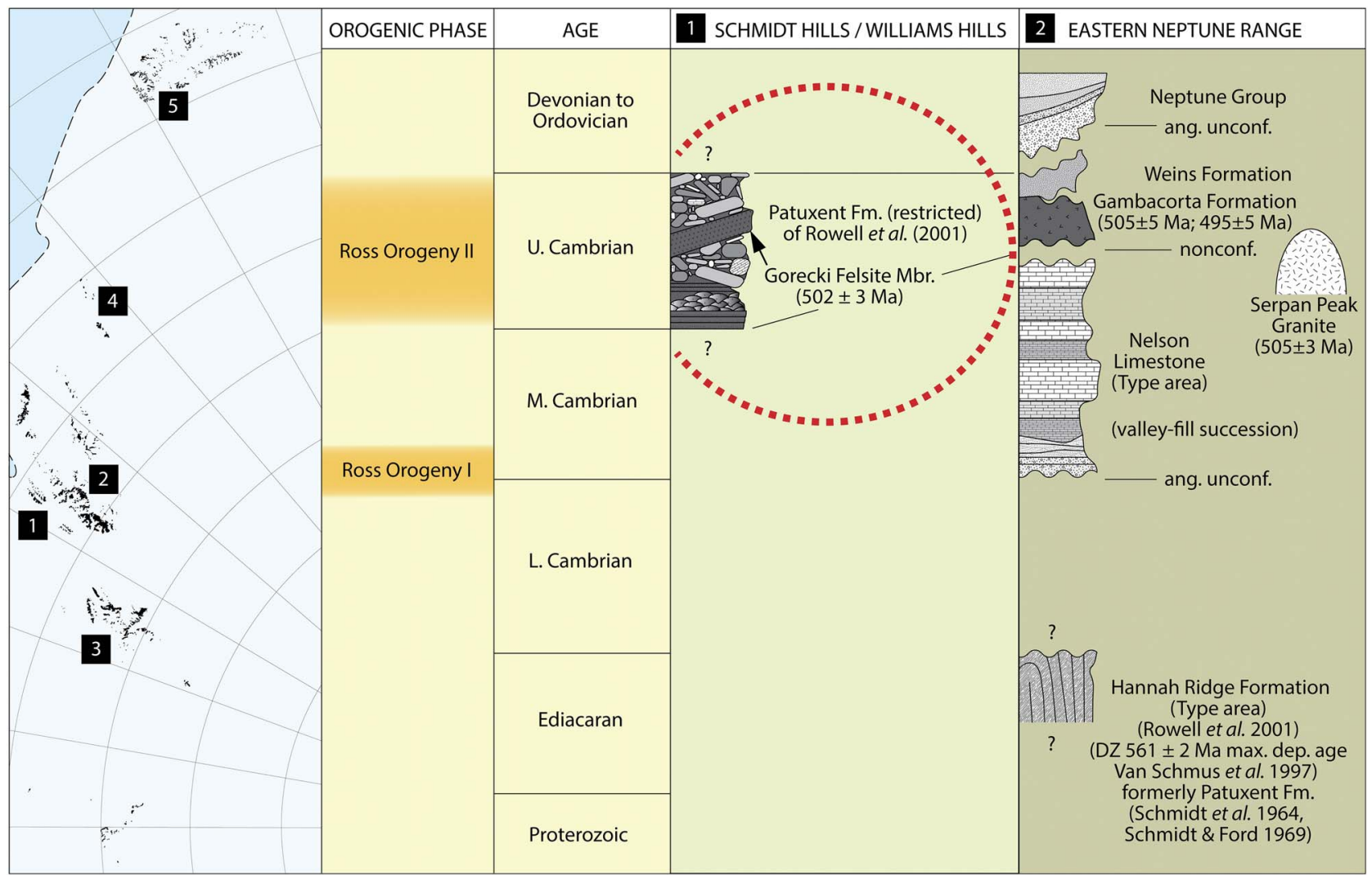

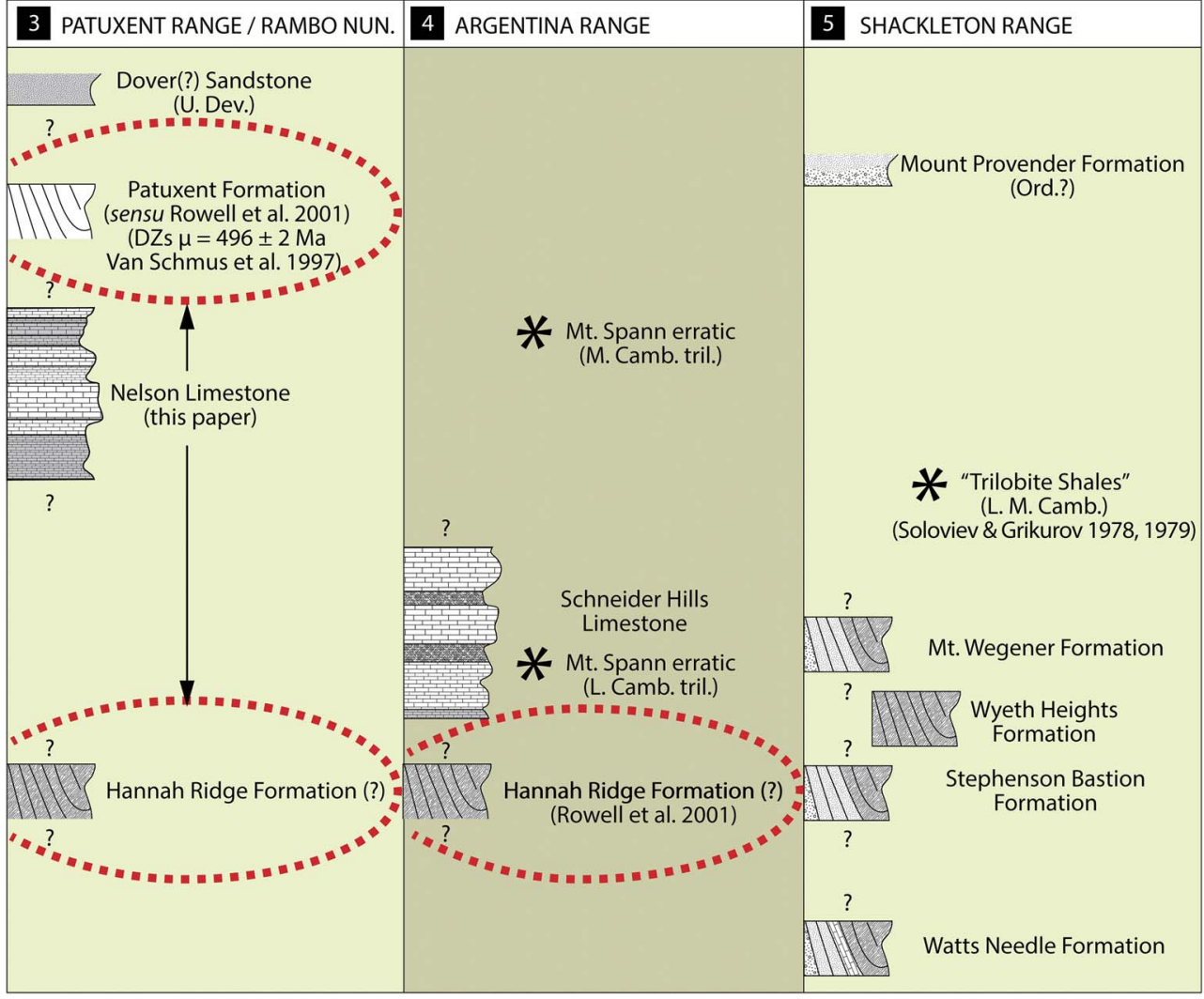

Fig. 9. Correlation chart of stratigraphic units in the Pensacola Mountains and adjacent mountain ranges. 
suggest this facies was closely linked and perhaps juxtaposed with the supratidal laminite and microbialite facies.

Burrow-mottled carbonate muds generally accumulate below normal fair weather wave base, but water depth may vary and can be fairly shallow in protected areas that are sheltered by barriers associated with supratidal carbonate banks. The presence of trilobites would indicate at least episodic normal salinity and shallow marine conditions, but the depauperate nature of the collections suggest a restricted setting. The sole fossiliferous interval from $318-322 \mathrm{~m}$ is relatively dark, suggestive of a higher content of organic carbon.

In the entire succession, depositional environments ranged from shallow subtidal to supratidal settings. Repeated shallowing-upward trends are recognized within the succession (Fig. 6), but it is difficult to determine from available information if these are related to an extrinsic forcing mechanism (e.g. Milankovitch cyclicity) or episodic allocyclic changes among facies within a broad, shallow depositional setting. A few smaller scale packages of cyclic carbonate laminae indicate tidal influence. From the unit thickness and trends in depositional environments, it would seem possible to correlate intervals of dominantly supratidal and subtidal lithofacies with three depositional cycles recognized in exposures of the Nelson Limestone in the Neptune Range (Evans et al. 1995), except for the fact that the base and top of the section at Postel Nunatak are not exposed. The marine interval present in the type area near Nelson Peak, above the mostly non-marine valley-fill sequence, include: i) an initial transgressive sequence dominated by muddy carbonates, ii) a carbonate shoal and iii) a deepening-shallowing succession that was truncated below volcanics of the Gambacorta Formation. Three distinct depositional sequences of strata are present at Postel Nunatak. All are shallow water successions, but the middle, dominantly lagoonal interval compares favourably with the middle carbonate shoal interval in the Neptune Range. In both the Neptune and Patuxent ranges, depositional environments abruptly deepen in the overlying upper sequence, where mud-dominated subtidal successions have yielded a trilobite fauna. The upper sequence has yielded the Amphoton oatesi Palmer \& Gatehouse zone fauna in both areas (Lieberman 2004). Regardless of the plausible intraformational correlations, the shallow water succession at Postel Nunatak is clearly a more restricted setting, and one can argue from distribution of the Nelson Limestone that the Neptune Range was located in a basinward setting, which is consistent with deepening toward the north illustrated in a cross-section of Nelson Limestone in the Neptune Range (Evans et al. 1995, Fig. 5).

The carbon isotope trend at Postel Nunatak is intriguing and surprisingly coherent given that we were working from a limited number of samples collected to document lithology. Further, screening for strong diagenetic overprints using correlation with $\delta^{18} \mathrm{O}$ values, suggests $\delta^{13} \mathrm{C}$ values may approximate depositional values in many samples. It seems higher resolution sampling would have good potential for documenting patterns of secular variation that reflect regional and global changes to carbon cycling and can be useful in chemostratigraphic correlations.

With the caveat explicitly stated that our sample spacing is too coarse to provide meaningful independent constraints on interpretations, we suggest the $\delta^{13} \mathrm{C}$ data do support a working hypothesis concerning the chronostratigraphic position of the Nelson Limestone when combined with stratigraphic and palaeontological observations. Specifically, the pattern of variation within the Nelson Limestone compares favourably with the Drumian carbon isotope excursion (DICE). The DICE event in Cambrian Series 3 is a significant shift in the chemostratigraphic record found a little above the first appearance datum of Ptychagnostus atavus (Tullberg 1880), and it has been recognized in many parts of the world (Zhu et al. 2006, Babcock et al. 2007, Howley \& Jiang 2010).

Other implications from this project have bearing on the status of what has been termed the Patuxent Formation in Antarctica (Fig. 9). Much of what had been originally mapped as Patuxent Formation in the Neptune Range was initially treated as Precambrian (Schmidt et al. 1978). Rowell et al. (2001) reported that deformed rocks cut by angular unconformity below the Nelson Limestone in the eastern Neptune Range have yielded detrital zircons that are Neoproterozoic in age although some strata may be partly correlative with the early Cambrian (Terreneuvian Series) in age. In contrast, rocks mapped as Patuxent Formation in the Schmidt Hills, Williams Hills, Rambo Nunataks and one sample from the Patuxent Range have yielded post-late middle Cambrian isotopic age dates (Van Schmus et al. 1997, Rowell et al. 2001). Rowell et al. (2001) referred to the latter as Patuxent Formation in a restricted sense and proposed the name Hannah Ridge Formation for siliciclastic rocks that are demonstrably truncated below the Nelson Limestone in the eastern Neptune Range. These stratigraphic relationships have led some investigators (e.g. Curtis et al. 2004) to suggest that Patuxent Formation in the Patuxent Range may be entirely post-middle Cambrian (Furongian Series) in age. This assignment could be problematic as it suggests that deep water siliciclastic deposition of several thousand metres of turbiditic sandstone and quartzite (see Schmidt \& Ford 1969) would have post-dated deposition of the Nelson Limestone, and that the entirety of the Patuxent Formation would be correlative with volcanic rocks of the Gambacorta Formation and overlying Weins Formation in the Neptune Range. At present, there is no tectonic mechanism that could explain this association. 
Instead, the distribution, depositional settings and level of deformation of the Nelson Limestone, especially in the Patuxent Range, would suggest that at least part of what was originally mapped as the Patuxent Formation by Schmidt \& Ford (1969) may be older than the Nelson Limestone and correlative with the Hannah Ridge Formation of the eastern Neptune Range (Fig. 9). This uncertainty in the stratigraphic position of the Patuxent Formation and its relationship to the Hannah Ridge Formation has implications regionally and is not independent from our understanding of the relationship between the Hannah Ridge Formation and the lower Cambrian Schneider Hills Limestone in the Argentina Range (e.g. Faure \& Mensing 2010, p. 246).

\section{Conclusions}

We confirm that limestone exposures at Postel Nunatak are correlated with the late middle Cambrian Nelson Limestone of the Neptune Range. Trilobites from the upper part of these exposures help to establish a Drumian or earliest Guzhangian age (Cambrian Series 3) for the uppermost strata. Carbonate lithofacies are interpreted as shallow subtidal marine and peritidal deposits. The regional distribution of the Nelson Limestone indicates an overall basinward direction and relative deepening to the north. Stable isotopic analyses are consistent with these findings and suggest potential exists for chemostratigraphic study including the possibility of documenting the position of the middle Cambrian DICE event within the section, but further study at higher resolution is needed to realize this goal.

\section{Acknowledgements}

This work was made possible through grants from the National Science Foundation Office of Polar Programs, numbers DPP 9117444 and OPP-9909302 to the University of Kansas. We are grateful to the staff and contractors serving the US Antarctic Program McMurdo Station for their mission support. We also want to thank our pilot Harry Hanlan and his flight crew from Kenn Borek Air for their support in the deep field. We thank reviewers and editors of the manuscript for their thoughtful comments, which greatly improved this paper. We are grateful to Julien Kimmig for facilitating the loan of specimens and also assistance with specimen photography, and also to the Departments of Ecology \& Evolutionary Biology and Geology for providing resources. Evans was supported for writing and further investigation of the material presented here during sabbatical leave from Missouri State University; he is grateful for assistance with arranging the sabbatical from the Graduate College, College of Natural and Applied
Sciences, and Department of Geography, Geology, and Planning. He also thanks Sara Ratcliffe for assistance scanning black and white film, along with various colleagues at the University of Swansea for resource support during the course of his sabbatical.

\section{Author contributions}

The efforts of each author are 20\%. Evans oversaw the project, wrote part of the manuscript and participated in the collection of field data. McKenna wrote part of the manuscript and participated in the collection of field data. Lieberman wrote part of the manuscript, prepared and identified the trilobites, and continues to manage the lithologic sample and faunal collections. Weichert wrote a portion of the manuscript and oversaw the sample preparations for examining stable isotopes. MacLeod wrote part of the manuscript, ran isotopic sample analyses and interpreted the data. In addition to individual contributions, each author collectively contributed to the overall editing and organization of the manuscript.

\section{References}

Ager, D.V. 1974. Storm deposits in Jurassic of Moroccan High Atlas. Palaeogeography Palaeoclimatology Palaeoecology, 15, 83-93.

BAвсоск, L.E., Robison, R.A., Rees, M.N., Peng, S.C. \& SAltzman, M.R. 2007. The global boundary stratotype section and point (GSSP) of the Drumian Stage (Cambrian) in the Drum Mountains, Utah, USA. Episodes, 30, 85-95.

Bassett-Butt, L. 2016. Systematics, biostratigraphy and biogeography of brachiopods and other fossils from the middle Cambrian Nelson Limestone, Antarctica. Geologiska Föreningen i Stockholm Förhandlingar (GFF), 138, 377-392.

Bentley, C.J., JAGO, J.B. \& Cooper, R.A. 2016. Cambrian Series 3 (Drumian) trilobites from limestone olistoliths, Reilly Ridge, northern Victoria Land, Antarctica. In LAurie, J.R., Percival, I.G., Jago, J.B., Paterson, J.R. \& Brock, G.A., eds. Cambro-Ordovician studies VI. Hornsby, NSW: Geological Society of Australia, 51-74.

Burton-Johnson, A., Black, M., Fretwell, P.T. \& Kaluza-Gilbert, J. 2016. An automated methodology for differentiating rock from snow, clouds and sea in Antarctica from Landsat 8 imagery: a new rock outcrop map and area estimation for the entire Antarctic continent. Cryosphere, 10, 1665-1677.

Cooper, R.A., JAGO, J.B. \& BEGG, J.G. 1996. Cambrian trilobites from northern Victoria Land, Antarctica and their stratigraphic implications. New Zealand Journal of Geology and Geophysics, 39, 363-387.

Curtis, M.L. 2002. Palaeozoic to Mesozoic polyphase deformation of the Patuxent Range, Pensacola Mountains, Antarctica. Antarctic Science, 14, 175-183.

Curtis, M.L. \& Storey, B.C. 2003. Early Palaezoic near-surface deformation in the Neptune Range, Antarctica: implications for the Ross and Gondwanian orogenies. Journal of the Geological Society, 160, 629-642.

Curtis, M.L., Millar, I.L., Storey, B.C. \& Fanning, M. 2004. Structure and geochronological constraints of early Ross orogenic deformation in the Pensacola Mountains, Antarctica. Geological Society of America Bulletin, 116, 619-636. 
Encarnación, J., Rowell, A.J. \& Grunow, A.M. 1999. A U-Pb age for the Cambrian Taylor Formation, Antarctica: implications for the Cambrian time scale. Journal of Geology, 107, 497-504.

Enos, P. \& Perkins, R.D. 1979. Evolution of Florida Bay from island stratigraphy. Geological Society of America Bulletin, 90, 59-83.

Evans, K.R., Rowell, A.J. \& Rees, M.N. 1995. Sea-level changes and stratigraphy of the Nelson Limestone (middle Cambrian), Neptune Range, Antarctica. Journal of Sedimentary Research - Stratigraphy and Global Studies, B65, 32-45.

Faure, G. \& Mensing, T.M. 2010. The Transantarctic Mountains. Rocks, ice, meteorites and water. New York, NY: Springer, 804 pp.

Federico, L., Crispini, L., Capponi, G. \& Bradshaw, J.D. 2009. The Cambrian Ross Orogeny in northern Victoria Land (Antarctica) and New Zealand: a synthesis. Gondwana Research, 15, 188-196.

GinsBurG, R.N., ed. 1975. Tidal deposits: a casebook of recent examples and fossil counterparts. New York, NY: Springer, $432 \mathrm{pp}$.

Howley, R.A. \& Jiang, G.Q. 2010. The Cambrian Drumian carbon isotope excursion (DICE) in the Great Basin, western United States. Palaeogeography Palaeoclimatology Palaeoecology, 296, 138-150.

JAGO, J.B. \& CoOper, R.A. 2007. Middle Cambrian trilobites from Reilly Ridge, northern Victoria Land, Antarctica. Memoirs of the Association of Australasian Palaeontologists, 34, 473-487.

JAGO, J.B. \& Webers, G.F. 1992. Middle Cambrian trilobites from the Ellsworth Mountains, West Antarctica. In Webers, G.F., Craddock, C. \& Splettstoesser, J.F., eds. Geology and paleontology of the Ellsworth Mountains, West Antarctica. Boulder, CO: Geological Society of America, 101-124.

Jago, J.B., Bentley, C.J. \& Cooper, R.A. 2011. A Cambrian Series 3 (Guzhangian) fauna with Centropleura from northern Victoria Land, Antarctica. Memoirs of the Association of Australasian Palaeontologists, 42, 15-35.

Lieberman, B.S. 2004. Revised biostratigraphy, systematics, and paleobiogeography of the trilobites from the Middle Cambrian Nelson Limestone, Antarctica. Lawrence, KS: University of Kansas Paleontological Institute, $23 \mathrm{pp}$.

O'NeIL, J.R. 1987. Preservation of H, C and O isotopic ratios in the low temperature environment. In KYSER, T.K., ed. Stable isotope geochemistry of low temperature fluids. Mineralogical Association of Canada Short Course Handbook, 13, 85-128.

Palmer, A.R. \& Gatehouse, C.G. 1972. Early and middle Cambrian trilobites from Antarctica. United States Geological Survey Professional Paper, 456-D, 1-36.

Palmer, A.R. \& Rowell, A.J. 1995. Early Cambrian trilobites from the Shackleton Limestone of the central Transantarctic Mountains. Journal of Paleontology, 69(Sup. 2), 1-28.

Rowell, A.J., Rees, M.N. \& Evans, K.R. 1992. Evidence of major middle Cambrian deformation in the Ross Orogen, Antarctica. Geology, 20, 31-34.
Rowell, A.J., van Schmus, W.R., Storey, B.C., Fetter, A.H. \& Evans, K.R. 2001. Latest Neoproterozoic to mid-Cambrian age for the main deformation phases of the Transantarctic Mountains: new stratigraphic and isotopic constraints from the Pensacola Mountains, Antarctica. Journal of the Geological Society, 158, 295-308.

SCHMidT, D.L. \& Ford, A.B. 1969. Geology of the Pensacola and Thiel mountains: Antarctica map folio series, folio 12 - Geology. New York, NY: American Geographical Society, plate V.

Schmidt, D.L., Williams, P.L. \& Nelson, W.H. 1978. Geologic map of the Schmidt Hills quadrangle and part of the Gambacorta Peak quadrangle, Pensacola Mountains, Antarctica. US Antarctic Research Program, Map A-8. Reston, VA: US Geological Survey.

Schmidt, D.L., Dover, J.H., Ford, A.B. \& Brown, R.D. 1964. Geology of the Patuxent Mountains. In AdIE, R.J., ed. Antarctic geology. Amsterdam: North Holland Publishing Company, 276-283.

Soloviev, I.A. \& Grikurov, G.E. 1978. Discovery of the first middle Cambrian trilobites from the Shackleton Range. Antarktika, 17, 187-198.

Soloviev, I.A. \& Grikurov, G.E. 1979. New findings about Cambrian trilobites from the Shackleton and Argentina ranges. USSR Academy of Sciences, Committee on Antarctic Research, 'Antarctica - The Committee Reports', 18, 54-73.

Soloviev, I.A., Popov, L.E. \& SAmsonov, U.V. 1984. New data on the upper Cambrian fauna of the Ellsworth and Pensacola mountains (western Antarctica). Antarktika, 23, 46-71.

Storey, B.C., MacDonald, D.I.M., Dalziel, I.W.D., Isbell, J.L. \& Millar, I.L. 1996. Early Paleozoic sedimentation, magmatism, and deformation in the Pensacola Mountains, Antarctica: the significance of the Ross Orogeny. Geological Society of America Bulletin, 108, 685-707.

Stump, E. 1995. The Ross Orogen of the Transantarctic Mountains. Cambridge: Cambridge University Press, $284 \mathrm{pp}$.

Tullberg, S.A. 1880. Om Agnostus-arterna i de Kambriska aflagringame vid Andrarum. Sveriges Geologiska Undersökning (Series C), 42, 1-37.

Van Schmus, W.R., McKenna, L.W. III, Gonzalez, D.A., Fetter, A.H. \& Rowell, A.J. 1997. U-Pb geochronology of parts of the Pensacola, Thiel, and Queen Maud mountains, Antarctica. In Ricci, C.A., ed. The Antarctic region: geological evolution and processes. Siena: Terra Antarctica Publication, 187-200.

WILSON, J.L. 1975. Carbonate facies in geologic history. New York, NY: Springer, $471 \mathrm{pp}$.

Wolfart, R. 1994. Middle Cambrian faunas (Brachiopoda, Mollusca, Trilobita) from exotic limestone blocks, Reilly Ridge, north Victoria Land, Antarctica: their biostratigraphic and palaeogeographic significance. Geologisches Jahrbuch (Reihe B), 84, 1-161.

Zhu, M.-Y., Babcock, L.E. \& Peng, S.-C. 2006. Advances in Cambrian stratigraphy and paleontology: integrating correlation techniques, paleobiology, taphonomy and paleoenvironmental reconstruction. Palaeoworld, 15, 217-222. 